\title{
The Granite and Glacial Landscapes of the Peneda-Gerês National Park
}

\author{
Paulo Pereira and Diamantino Insua Pereira
}

\begin{abstract}
Granite and glacial landforms are presented as the main geomorphological landscape features of the Peneda-Gerês National Park. The park was established in 1971 and it is the only national park and most important protected area in Portugal. The aesthetic attractiveness is supported mainly by the distinct granite landscape of the Gerês and Peneda Mountains, where the post-orogenic Variscan Gerês granite facies occurs. The rugged relief is poorly covered by vegetation, differentiating it from the surrounding mountainous areas and the most distinctive landforms are bornhardts, locally named as "medas". Typical glacial landforms, such as U-shaped valleys, cirques and moraines, express the sheltered character of a low-altitude glaciation, which is of great significance in the context of the Pleistocene glaciation in Southern Europe.
\end{abstract}

\section{Keywords}

Granite - Glaciation - Serra da Peneda •

Serra do Gerês • National park

\subsection{Introduction}

The Peneda-Gerês National Park (PGNP) is located in North-west Portugal and is the only national park in the country, which is the highest status for protected areas. It was established by Decree-Law 187/71 on 8 May 1971 over an area of $709 \mathrm{~km}^{2}$ due to its remarkable natural and cultural

P. Pereira $(\bowtie) \cdot$ D. I. Pereira

Institute of Earth Sciences, Pole of the University of Minho,

Braga, Portugal

e-mail: paolo@dct.uminho.pt

D. I. Pereira

e-mail: insuad@dct.uminho.pt features, which are present in the Peneda, Amarela and Gerês Mountains close to the border with Spain (Fig. 10.1).

The majority of the park's territory rises above $1000 \mathrm{~m}$ asl, with the highest peak being Pico da Nevosa in the Serra do Gerês at $1546 \mathrm{~m}$. The Serra da Peneda has its highest point at Pedrada at $1416 \mathrm{~m}$ and the Serra Amarela at Louriça at $1359 \mathrm{~m}$. These mountains are the westernmost branch of the north-western Iberia mountain ranges and also part of the north to south orographic barrier that influences the high rainfall values, which are among the highest in Europe (Trigo and DaCâmara 2000). In PGNP, the mean annual totals may be greater than $3000 \mathrm{~mm}$ (Daveau et al. 1977).

The creation of PGNP as the country's first protected area was a landmark in nature conservation policies in Portugal, together with the first national legislation for nature protection in the same year. These accomplishments resulted mostly from national and international demands to the Portuguese authorities during the celebration activities for the European Year of Nature Conservation in 1970.

The "wilderness model" of the American National Parks system was chosen as the model for this territory, as it is a national symbol for nature protection. Since then, PGNP has become the most iconic protected area in Portugal, with a landscape where traditional human activities have been reduced and wilderness is valued.

After the political changes in Portugal in 1974, the "wilderness model" was replaced by a "landscape model" with the purpose of conserving landscapes resulting from traditional agro-pastoral activities and other associated cultural values. This determined the PGNP management that followed and also led to the establishment of new types of protected areas in Portugal under the status of Natural Parks (Pinto and Partidário 2012).

PGNP is generally recognised, both nationally and internationally, as an area with rich biodiversity, e.g. endemic plant species and wild animals. Nevertheless, it is mainly the peculiar granite landscape of the Gerês and 


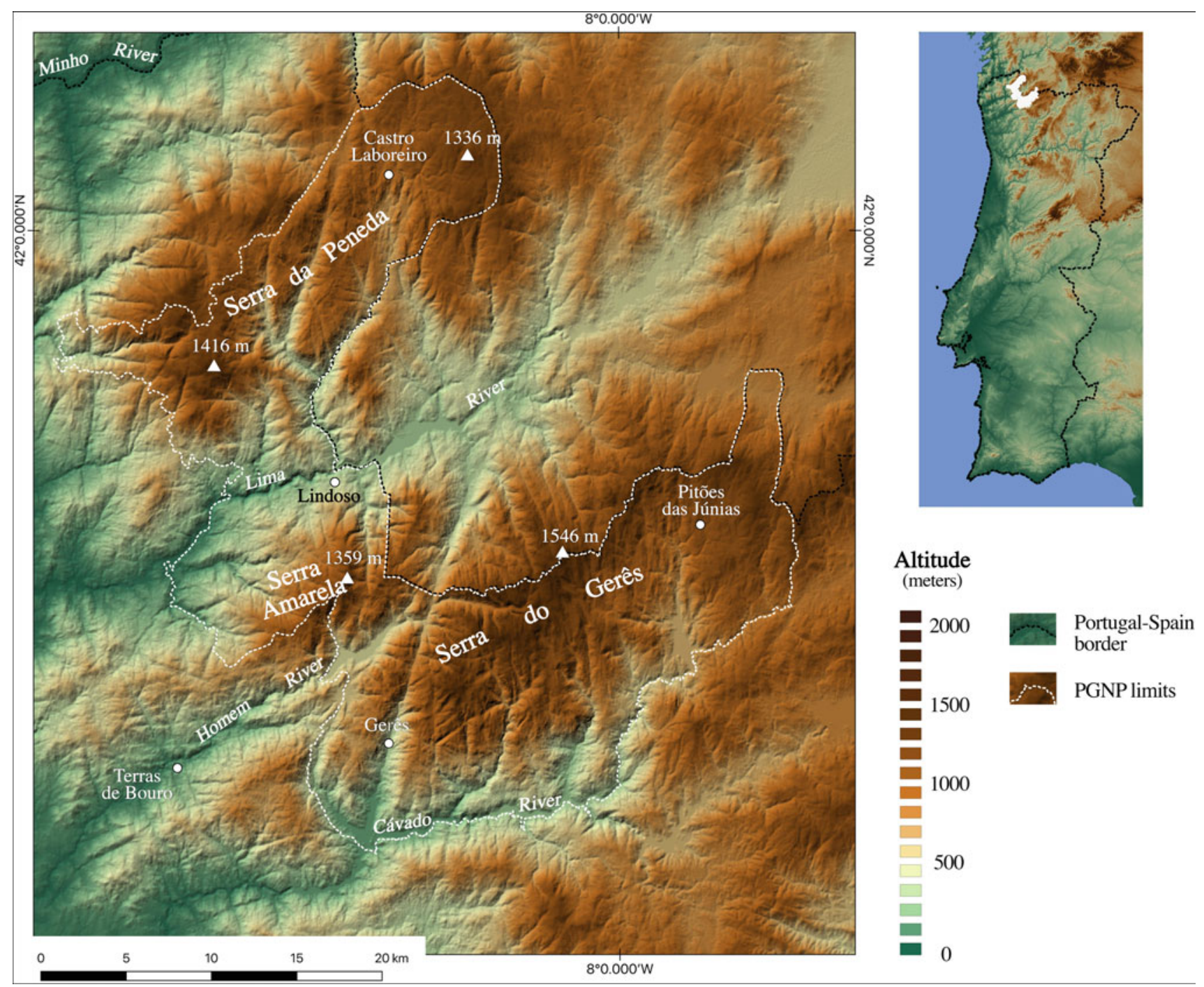

Fig. 10.1 Location of Peneda-Gerês National Park in the Portuguese territory, with the main mountains and rivers

Peneda Mountains that sustains the aesthetic attractiveness of the park.

In this chapter, geomorphological characterisation of PGNP is presented, with special emphasis on granite and glacial landforms that shape the scenery of the most important protected area in Portugal.

\subsection{Geological Setting}

The PGNP territory is dominated by granitic rocks that were emplaced in the continental crust 320-290 Ma ago, during the Variscan orogeny (Fig. 10.2). At the same time, sedimentary rocks of Silurian age (435-408 Ma) were deformed and metamorphosed to become schists, metagreywackes and quartzites, which are present in the NW sector of the park.
Dykes and sills of basic rocks, quartz and aplite-pegmatites crosscut the granites and the metamorphic rocks.

Some of the quartz and aplite-pegmatite dykes are mineralised and, in the past, mining exploration for tin, tungsten, molybdenum and gold was undertaken. Unfortunately, due to these mining activities, much of the mineralogical heritage of the park has been destroyed through the years (Brilha et al. 1999).

The most representative occurrence of granitic rocks in the PGNP is the Peneda-Gerês pluton, a distinctive example of the late to post-orogenic plutons in the Iberian Palaeozoic massif. It outcrops over an area of about $800 \mathrm{~km}^{2}$ across the border between Portugal and Spain, covering the majority of the Peneda and Gerês Mountains. The pluton is the result of emplacement of three coeval and independent $\mathrm{Fe}-\mathrm{K}$ sub-alkaline magmas with a primitive $\mathrm{Sr}-\mathrm{Nd}$ isotopic composition that intruded syn-D3 and late-D3 granites and 


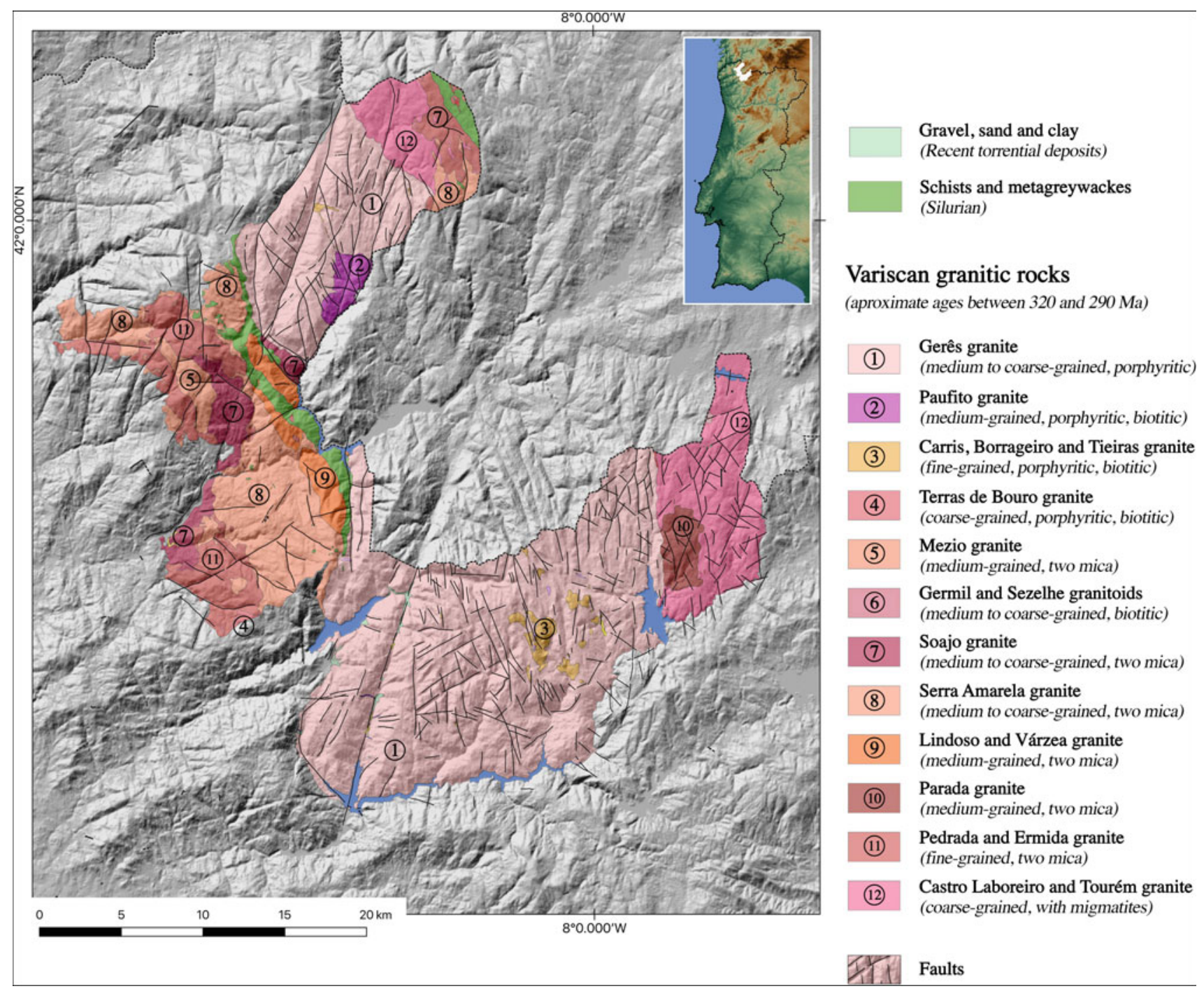

Fig. 10.2 Simplified geological map of the Peneda-Gerês National Park. Adapted from Moreira and Ribeiro (1991)

Silurian metasedimentary rocks. U-Pb geochronological data indicate an emplacement age from 290 to $296 \mathrm{Ma}$ (Dias et al. 1998), being the youngest granites in the PGNP area (Mendes and Dias 2004).

The most extensive unit is the Gerês granite, a porphyritic, medium to coarse-grained, slightly rose-coloured, biotite monzogranite. Towards the interior of the massif, this granite adjoins the Paufito granite, a porphyritic, medium-grained, biotite monzogranite whose porphyritic character disappears and whose grain size decreases towards the innermost unit (the Illa granite, which is a two-mica, fine-grained monzogranite, not cropping out within the PGNP). In the Gerês granite, irregular masses of fine-grained, slightly porphyritic, biotite monzogranite occur and are referred to as the Carris granite. Some of these granitic rocks were affected by hydrothermal alteration and transformed to episyenites (Mendes and Dias 2004).
In the southern part of the Serra da Peneda and in the Serra Amarela, syn-D3 and late-D3 two-mica granites occur. The Soajo and Serra Amarela medium to coarse-grained granites and Pedrada and Ermida fine-grained, two-mica granite are the most extensive. In the Castro Laboreiro and Tourém regions (in the northern and eastern extremes of the park, respectively), a coarse-grained, nodular granite containing migmatites occurs (Fig. 10.2).

A dense fracture network affects the rocks and it is particularly visible at higher altitudes, where the granites crop out in sparsely vegetated terrain. The Senhora da Peneda and Lovios-Gerês NNE-SSW strike-slip faults cause the rivers to form deep, straight valleys with the same direction in the Peneda and Gerês, respectively. Besides these, the Lima and Cávado rivers cross the PGNP area in an ENE-WSW direction and many secondary rivers follow NNW-SSE and $\mathrm{N}-\mathrm{S}$ directions. The occurrence of hot springs, both in the 
PGNP area and in Spain, is related to these fault and fracture systems and mainly to those with a NNE-SSW alignment.

\subsection{The Granite Landscapes of Peneda-Gerês National Park}

The fault and fracture systems inherited from the late phases of the Variscan orogeny were reactivated in response to compressive tectonic episodes that have affected the Iberian Peninsula since the end of the Cretaceous.

The mountains in the PGNP form the western branch of the Cantabrian Mountains, where uplift is related to the subduction of the European plate under the Iberian Plate in the Bay of Biscay, which occurred throughout the Cenozoic. Paleogene and Neogene fluvial sediments occurring in the northern Iberia are evidence of the tectonic stages of this earlier uplift (Cloetingh et al. 2002).

In the Eocene, intense tectonic movements formed a series of uplifted blocks and basins, reactivated during the late Cenozoic, since the Middle Tortonian, under the influence of a NNW-SSE- to NW-SE-oriented compression (Cunha et al. 2000). The vertical uplift of the PGNP region during the last $3 \mathrm{Ma}$ was interpreted as being from 200 to $500 \mathrm{~m}$ (Cabral 2012).

The uplift of the PGNP area and the subsequent entrenchment of rivers forming the deep valleys resulted in rugged relief that reflects lithological and tectonic constraints (Fig. 10.3). Despite the irregular terrain, a few planation surfaces persist in the Mourela region in the eastern part of the park, connecting the Gerês and Larouco Mountains and also in the Castro Laboreiro region in the far north of the park, where the same granite occurs (Castro Laboreiro and Tourém granites, with migmatites). In Mourela, the plateau sits at 1000-1100 m asl, and in Castro Laboreiro, it is present between 1250 and $1300 \mathrm{~m}$ asl.

In the rest of the park, the planation levels are scarce, poorly preserved and discontinuous, with the most elevated ones between 1400 and $1450 \mathrm{~m}$ asl in Gerês and between 1250 and $1300 \mathrm{~m}$ asl in Peneda (Coudé-Gaussen 1981). Nevertheless, the contrast between the interfluves and the steep slopes of the valleys makes the summits look planar. Below the highest summits, the planation levels are generally unclear, with the lowest ones at altitudes of approximately $500 \mathrm{~m}$ asl (Ferreira et al. 1999).

The steep gradient between the highest levels and the deepest valley floors is the reason for waterfalls to occur, forming well-known landmarks of the PGNP (Fig. 10.4). These waterfalls are generally small, ranging from 5 to $30 \mathrm{~m}$ in height, and mostly occur on the southern slopes of the Serra do Gerês, where small tributary streams rapidly fall from the highest levels to the bottom of the deep Cávado river valley.

A rough relief, with poor vegetation cover, occurs in the Serra do Gerês and in the central part of the Serra da Peneda, differentiating them from the surrounding mountainous areas (Pereira et al. 2014) (Fig. 10.5). This constitutes one of the main elements of the landscape in the PGNP and is clearly connected with the occurrence of the Gerês granite.

In these areas, the most distinctive landforms are bornhardts (Fig. 10.6), which are major convex landforms or megaforms that are normally higher than $100 \mathrm{~m}$ (Twidale 1982; Twidale and Vidal Romaní 2005). They are poorly fractured residual hills that were defined by the primary

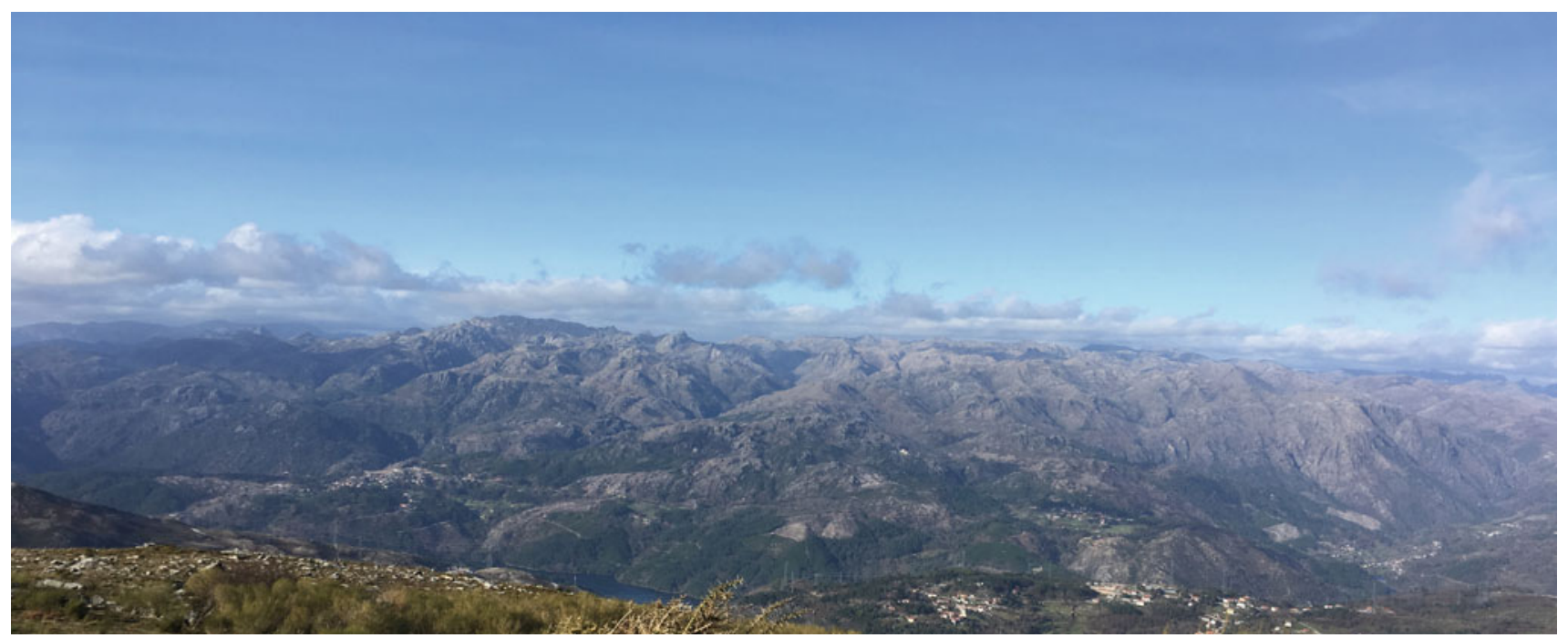

Fig. 10.3 Panoramic view of the Serra do Gerês from the south 

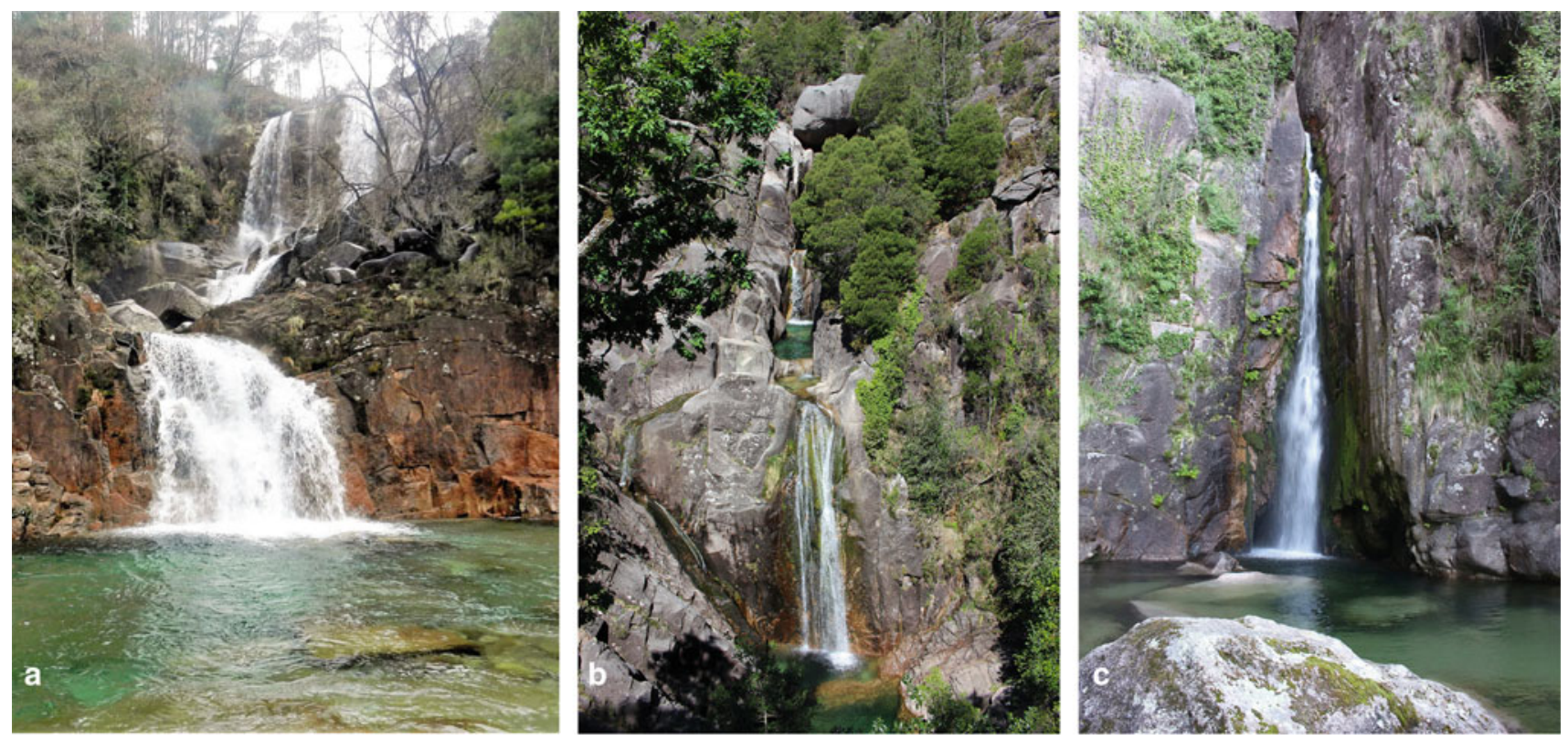

Fig. 10.4 Examples of waterfalls on the southern slopes of the Serra do Gerês, namely Tahiti (a) and Arado (b) waterfalls on the Arado river and the Pincães river waterfall (c) near the village of the same name

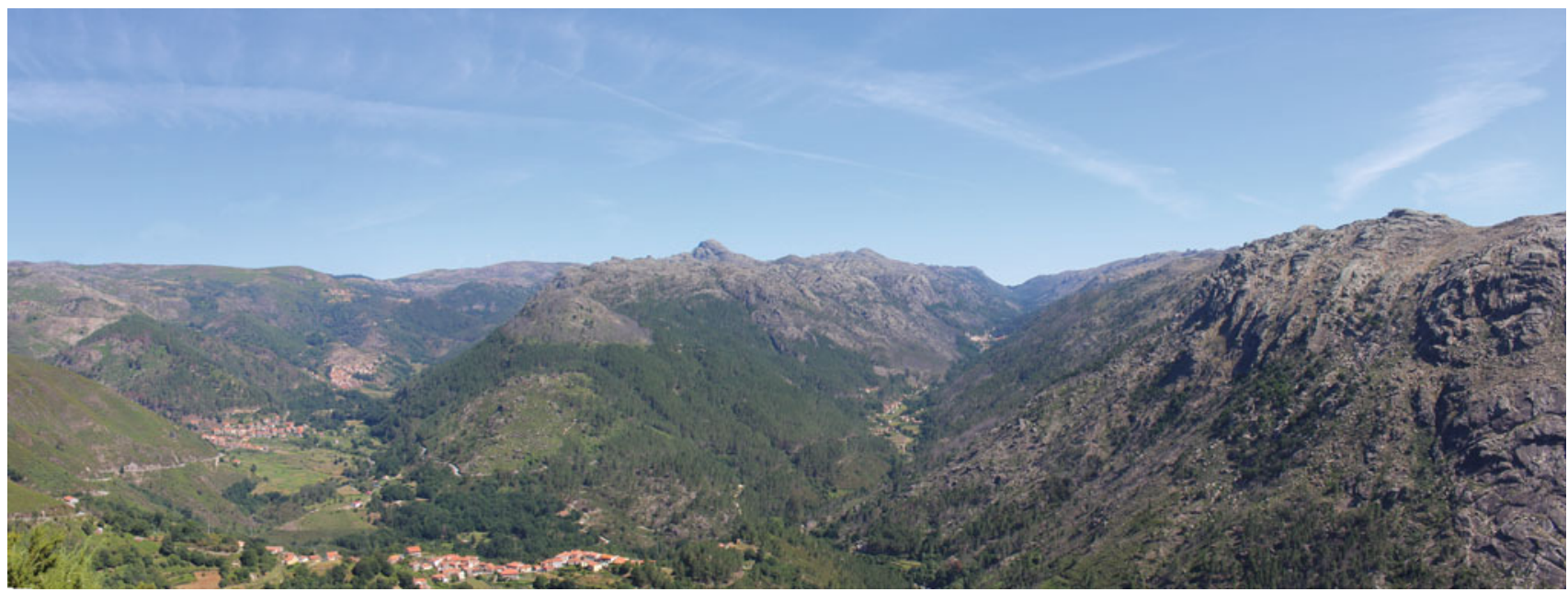

Fig. 10.5 Contrast of the contiguous granite landscapes in the Gavieira and Senhora da Peneda valleys (Serra da Peneda): a rugged relief with steep slopes and poorly covered by vegetation, where the
Gerês granite occurs (right side of the picture) and smoother summits and slopes and more vegetation cover, in the Serra Amarela granite area (left side of the picture) intrusive structure of the granitic rock and exposed by the erosion of the rocks in which they intruded (Vidal Romani et al. 2014).

The bornhardt landforms in the PGNP, that stand tens of metres high, are locally called "medas" and "borrageiros". According to Vidal Romani et al. (1990a) and Ferreira et al. (1999), the "medas" are, in fact, bornhardt landforms while "borrageiros" are castle kopje, controlled by systems of sub-vertical fractures and linked to the development of orthogonal joints. Smaller residual hills, like tors, are also frequent in the Gerês granite.

The action of atmospheric agents on granitic rocks, together with jointing, has created typical granite microforms (such as gnammas, rills and pseudobedding) in all types of granites in the PGNP.

Gnammas (weathering pits) are small concavities on the surface of granite boulders and are very common in the granite landscapes of northern Portugal and Galicia (Vidal Romani 

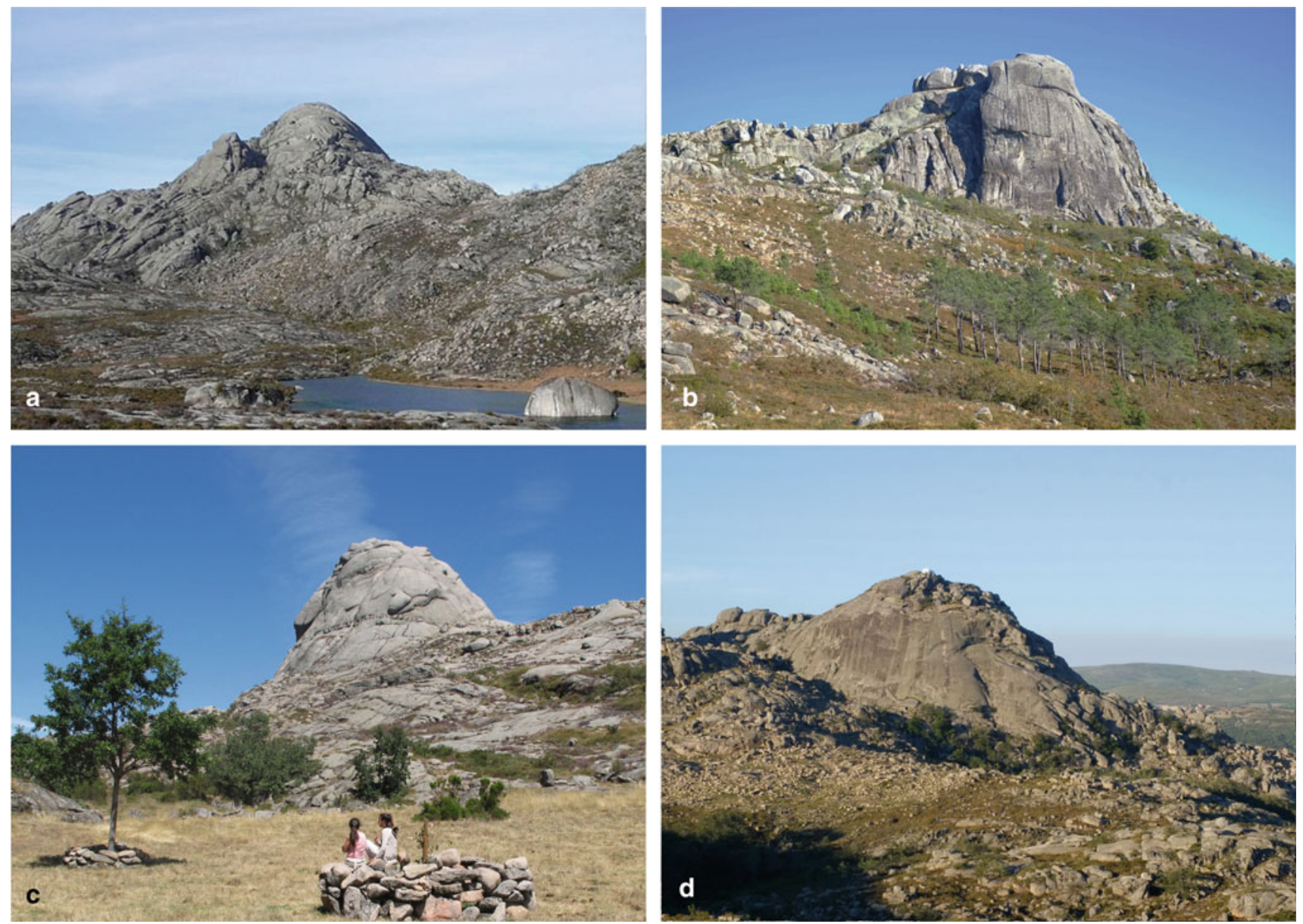

Fig. 10.6 Examples of bornhardt landforms in the Peneda-Gerês National Park: a Penameda and b Pena de Numão in the Serra da Peneda, c Rocalva and d São João das Júnias in the Serra do Gerês

et al. 2014) though they are smaller and not fully developed in glaciated areas. Rills correspond to channel-shaped features that concentrate run-off over the horizontal granite surfaces. Tafoni are shallow caverns or hollows enclosed through the preservation of a visor, or hood (Twidale and Vidal Romaní 2005). These are very rare landforms in the Gerês granite though some examples occur in the Serra da Peneda, near Soajo village (Lindoso and Várzea granite).

Pseudobedding occurs in different types of granite in the north of Portugal, preferentially at the top of the highest mountains. Weathering is controlled by foliation planes in granites with well-developed deformation by shearing (Twidale and Vidal Romaní 2005; Migon 2006) and discontinuous layers (sheet structure), typically being a few centimetres to decimetres thick. In the PGNP, this is particularly evident in the Pedrada and Ermida granite outcrops (Serra da Peneda), where granite slabs cover the highest slopes.

\subsection{The Glacial Landscapes of Peneda-Gerês National Park}

The first references to glacial evidence in the north-western mountains of Portugal date from the late nineteenth century, but it was only in the 1950s that cirques, lakes, U-shaped valleys and moraines in the Serra do Gerês summits were identified as glacial landforms (Girão 1958). Even after more detailed studies presented by Schmidt-Thomé (1973, 1978) and Coudé-Gaussen $(1978,1979,1981)$, the latter presenting the first evidence of glaciation in the Peneda Mountain, the controversy among the scientific community continued, with standpoints ranging from full acceptance to formal rejection (Teixeira and Cardoso 1979; Martínez de Pisón and Arenillas 1979, 1984) of glaciation in these mountains (Ferreira et al. 1999). 
Nowadays, it is demonstrated that during the Late Pleistocene, the PGNP mountains were covered by a plateau ice field (Fig. 10.7) similar to those of the Serra da Estrela in central Portugal or in the Galician and Leonese Mountains nearby (Ancares, Courel, Queixa-Invernadoiro and Segundera-Cabrera). In the PGNP, the Pleistocene snow line is inferred as being approximately at $1000 \mathrm{~m}$ asl, although in Galicia, snow lines were reconstructed as being below $900 \mathrm{~m}$ asl on some mountains. The low-altitude glaciation of NW Portugal and Galicia has a great significance in palaeoclimatic terms, in the context of the southern Europe and Mediterranean glaciations (Hughes et al. 2006).

Typical glacial landforms, such as cirques and U-shaped valleys, can be observed in the Peneda and Gerês Mountains despite the absence of a typical alternation of overdeepenings and riegels in the valleys. Moreover, several moraines occur but the majority are simple alignments of rounded boulders in interfluve positions or along slopes and valleys. The best indicators for the limits of the glaciated areas are the contrast between the bare-rock landscape and the landscape where weathered rock prevails, and till deposits occurring in several outcrops, particularly lodgement till, presenting a strong compaction (Ferreira et al. 1999).

\subsubsection{The Serra do Gerês}

The most complete and accurate study of the Gerês Mountain glaciation was presented by Ferreira et al. (1999), following a previous analysis of tills and glacial landforms in some parts of the mountain (Vidal Romani et al. 1990b;
Ferreira et al. 1992) and reviewing the observations made by Schmidt-Thomé and Coudé-Gaussen in the 1970s.

Traces of glaciation are more evident in the eastern and southern parts of the mountain (Fig. 10.7a). This is regarded as the effect of an asymmetry in snow transport and its association with the oceanic air masses flow from north-west. Therefore, an ice field covered the summits in the eastern and central parts of the mountain at the maximum ice extent period, with outlet glaciers radiating into the peripheral valleys.

In the western part of the mountain, glacial traces are scarcer, although a subglacial till found at $725 \mathrm{~m}$ asl in the Homem river valley shows that the glacier descended at least to that point. In the more westerly Serra Amarela, the only traces are small moraines that correspond to an isolated glacier occurrence, with no spatial connection to the Gerês glaciation (Fig. 10.7a). In the north, on the slopes of the Spanish side, U-shaped valleys, striated rocks, moraines and lodgement tills occur down to an altitude of about $1000 \mathrm{~m}$ (Ferreira et al. 1999).

The Homem river upper valley is one of the best areas to observe and understand glacial processes that shaped the mountains. The upper valley is U-shaped and straight for about $4 \mathrm{~km}$, revealing abundant traces of glacial processes (Fig. 10.8a). Subglacial tills occur at various points in the valley, the best examples being near the Madorno and Cagarouço stream confluences, and the lowest occurrence being at the bridge of São Miguel. Because of the steep slopes, moraines did not persist in their original position after the glaciation. The valley floor is filled with fluvioglacial deposits, while the slope bases show taluses with thick periglacial slope deposits at some points. Some

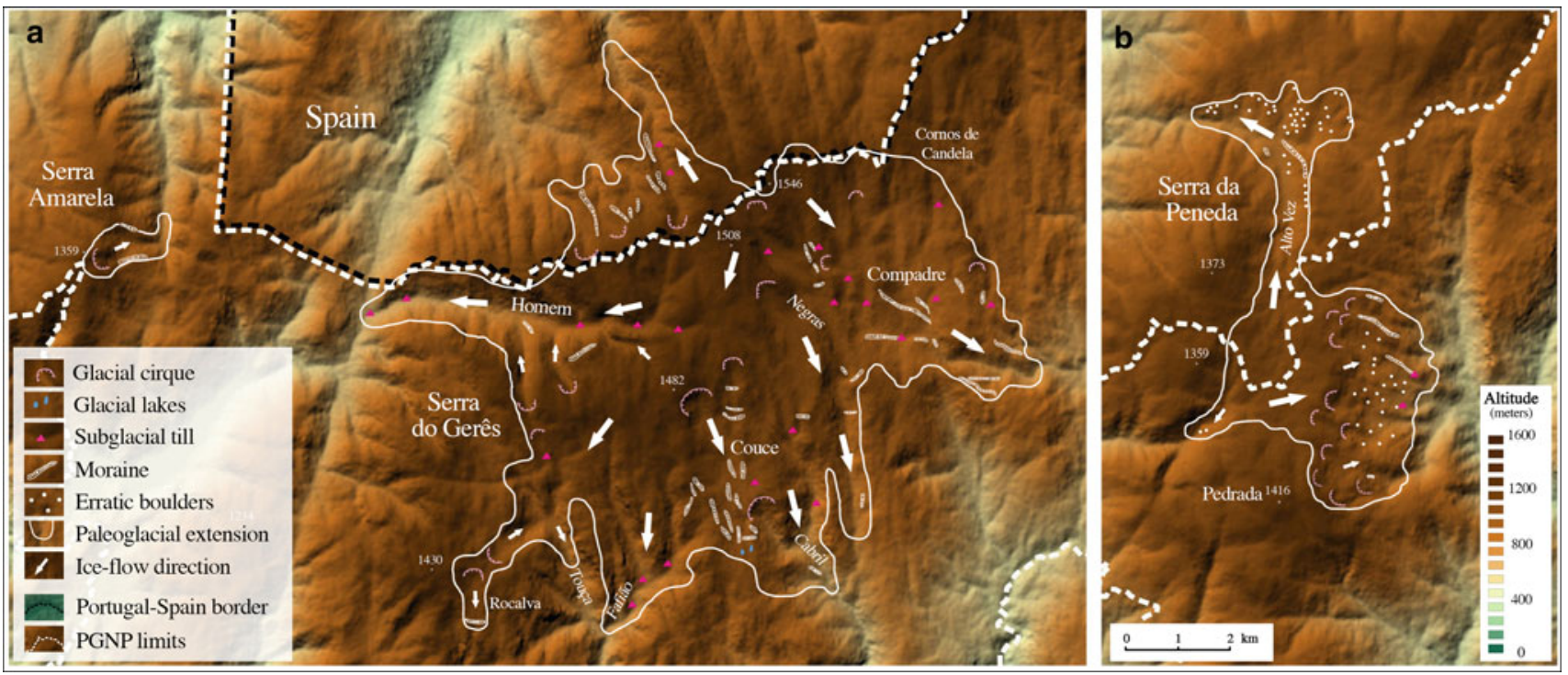

Fig. 10.7 Main glaciation indicators in PGNP mountains: a Serra do Gerês and Serra Amarela, b Serra da Peneda. Palaeoglacial extent is based on Coudé-Gaussen (1981), Vidal Romani et al. (1990b), Ferreira et al. (1999) and in personal observations 

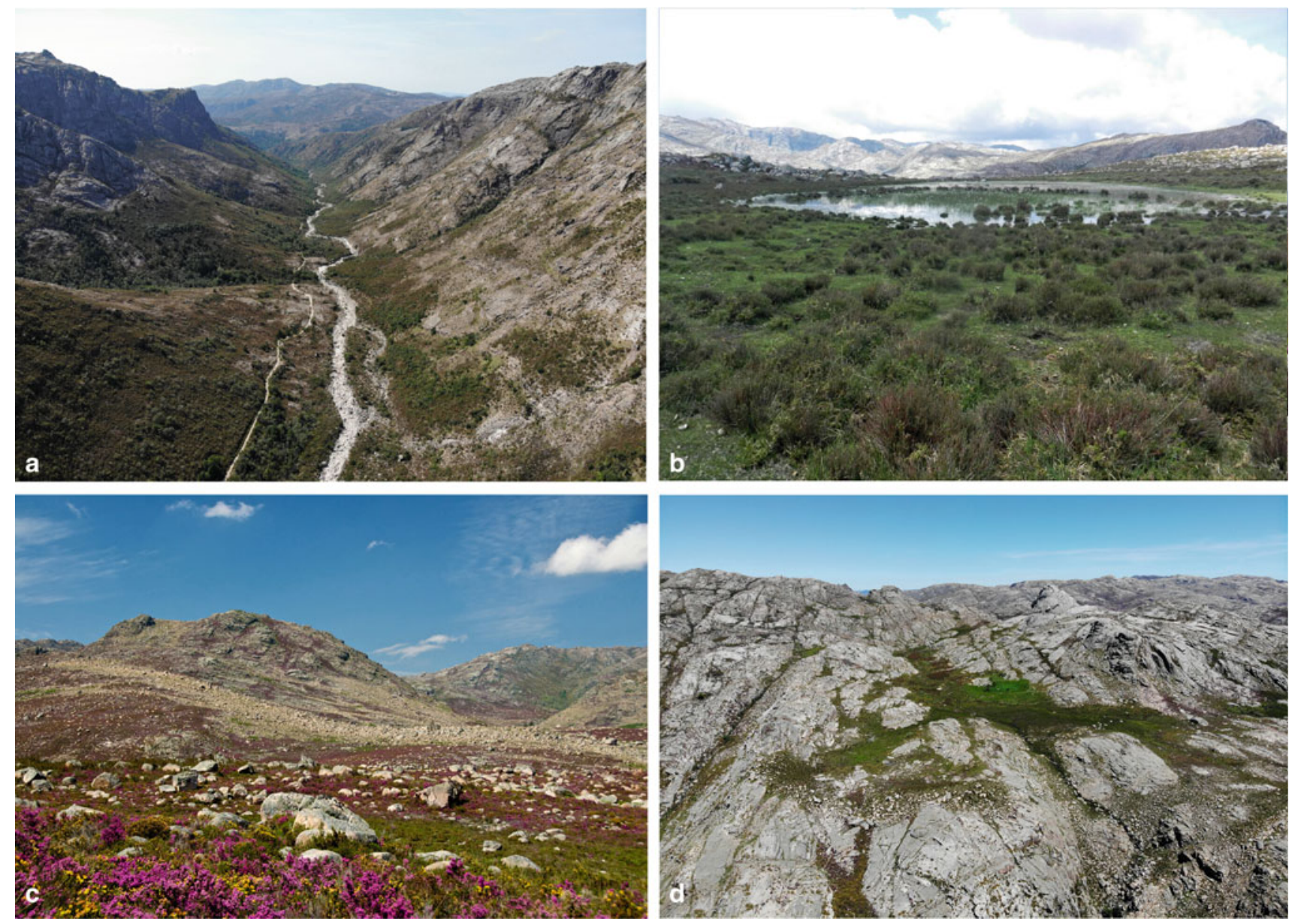

Fig. 10.8 Examples of glacial landforms in the Serra do Gerês: a Homem river U-shaped valley, b Marinho glacial lake in the headwaters of the Couce valley, c Compadre lateral moraine in the Biduiça valley and $\mathbf{d}$ Rocalva valley terminal moraines

moraines above the slopes indicate that the Homem glacier was about $300 \mathrm{~m}$ thick.

The Couce valley is another important site regarding glacial landforms in Gerês. Besides the Cocões de Concelinho cirque, which is considered to be one of the most typical glacial erosion landforms in the mountains (Ferreira et al. 1999), a set of moraines can be observed, indicating an ice thickness of about $150 \mathrm{~m}$ in the Couce valley. In the same area, there are small glacial lakes (Fig. 10.8b), the only ones present in the PGNP area and in northern Portugal.

The eastern part of the mountain is where the glaciation left most traces. Several moraines are evident in the Compadre sector, mainly the lateral moraine on the left slope of the Biduiça valley, which is more than $1 \mathrm{~km}$ long (Fig. 10.8c). In this sector, several till outcrops occur, allowing to set the limits of glaciation on the western slopes of Cornos de Candela and to define the maximum ice thickness of $150 \mathrm{~m}$. Near the highest peaks of Gerês, in the Ribeira das Negras valley, till sequences consist of lodgement till covered by subglacial melt-out till and large boulders, i.e. the remains of supraglacial till (Ferreira et al. 1999).

The described depositional sequences are essential to the interpretation of the glaciation in the Serra do Gerês (Santos et al. 2017). The sequence that occurs in the upper valley of the Fafião river (in the southern part), is a long, continuous outcrop of glacial sediments consisting of lodgement till covered by a fluvioglacial deposit and a supraglacial till at approximately $850 \mathrm{~m}$ asl. The lowest moraines in Gerês are also in the southern sector, located at around $775 \mathrm{~m}$ asl in the Cabril river valley.

In the Rocalva valley, which is located in the south-western sector of the mountains, two well-defined terminal moraines (Fig. 10.8d) and the scarcity of clearly erosional vestiges and till outcrops are clues that the local ice thickness was less than $50 \mathrm{~m}$ and that various advances and retreats of the local glacier occurred. These advances and retreats during the deglaciation stage cannot be accurately 
identified, although in some parts of Gerês diverse moraine positions point to the complexity of glacial retreat, with multiple stops followed by minor advances (Ferreira et al. 1999).

Chronological data, based on ${ }^{21} \mathrm{Ne}$ and ${ }^{10} \mathrm{Be}$ cosmogenic nuclides from two glacially polished surfaces on the Spanish slope of Gerês (Fernández Mosquera et al. 2000), provided ages of 238 and $130 \mathrm{ka}$, the former constituting the oldest date known for glaciation across the whole Iberian Peninsula (Vidal Romaní et al. 2015). However, based on the same dating techniques, the glacial record preserved in other NW Iberia ranges was inferred as formed during multiple stages of the last glacial cycle (Oliva et al. 2019). At the Trevinca massif, the best studied area in the NW ranges, the maximum ice extent was defined at ca. 33-48 ka with the glacier fronts remaining stable until ca. $22 \mathrm{ka}$ and recessing until ca. $15 \mathrm{ka}$, as suggests the oldest ${ }^{10} \mathrm{Be}$ ages obtained in the Sanabria Lake moraine complex (Rodríguez-Rodríguez et al. 2014). The ages set for Gerês sustain glaciations older than the last glacial cycle though more absolute dating studies are needed for a full understanding of the local glacial phases.

\subsubsection{Serra da Peneda}

Unlike the Gerês glaciation, the traces of the Serra da Peneda glaciation have only been known since the late 1970s (Daveau 1977; Coudé-Gaussen 1978), with less attention being given to them over the years and fewer studies focusing on glacial geomorphology. Although altitudes exceed $1300 \mathrm{~m}$ in the Castro Laboreiro region, clear glacial traces appear only in the westernmost part of the mountains (Fig. 10.7b), where the most elevated terrain has developed in the Pedrada and Serra Amarela granite facies (Figs. 10.1 and 10.2). An ice field was present there, covering the small plateau between 1150 and $1250 \mathrm{~m}$ asl at the maximum ice extent. The area shows a smooth topography characterised by the occurrence of peaty mountain soils and striated rock outcrops. The glacier ice flowed eastwards, surpassing the interfluves and descending the slopes of the right bank of the Gavieira river valley. It was a lee-side glaciation, which developed glaciers flowing to the lower valleys, similar to what happened in the Serra do Gerês.

Although slightly outside the PGNP area, the best glacial traces on the Serra da Peneda are to be observed in the north, below the plateau and down to an altitude of $850 \mathrm{~m}$. There, the Vez river valley is U-shaped (Fig. 10.9a) and a set of asymmetric roches moutonées can be observed. Glacial depositional landforms such as terminal, lateral and recessional moraines occur (Coudé-Gaussen 1979, 1981; Coudé et al. 1983), and these have recently been shown to contain both subglacial and supraglacial melt-out tills (Santos et al. 2015). Moreover, one of the most remarkable fields of glacial erratics in Portugal can be observed (Fig. 10.9b), with large, rounded granite boulders overlying schist outcrops near the Aveleira and Santo António villages ("brandas"). The altitude of the highest erratics supports the presence of over $100 \mathrm{~m}$ of glacier ice in that section of the valley during the glacial maximum.

On the western slopes of the Peneda massif, several groups of disperse moraines can be observed above the Gavieira and Rouças villages, making it difficult to define the glacial limits in this sector. However, at the head of the small streams descending that slope, well-defined glacial cirques can be seen, especially the Ramisquedo cirque has clear erosional features. A very compact deposit with a thickness of about $3 \mathrm{~m}$ was recently found near Branda da Junqueira at $900 \mathrm{~m}$ asl (Fig. 10.9c). This altitude is considered to be the limit of the glaciation in this sector of the mountain. Particle size, fabric and structure analyses indicate that these are subglacial lodgement tills (Pereira et al. 2009; Santos et al. 2015), which suggests that the extent of the Serra da Peneda glaciation should be re-evaluated.

Another typical landscape of this sector of the Serra da Peneda are blockfields and blockslopes, consisting of a surface layer of frost-shattered granite slabs over the highest summits and slopes, mainly where the Pedrada and Ermida fine-grained, two-mica granite facies occurs. These deposits are a consequence of frost-shattering facilitated by the pseudobedding, revealing the lack of glacial imprint but an intense action of periglacial processes. The most spectacular occurrence of this type is found in the Pedrada massif, near the summit. The concentration of these slabs over an area of approximately $3000 \mathrm{~m}^{2}$ (Fig. 10.9d) is very similar to that which occurs in the Serra da Estrela, specifically in the Alto da Pedrice (Vieira 1998).

\subsection{Conclusions}

The PGNP landscape is dominated by granite megaforms, mainly the ones occurring in the Gerês granite facies, which supports rugged relief, quite distinct from one in the other areas of the park. The scarce vegetation cover in the higher parts of the Gerês, Peneda and Amarela Mountains highlights the landforms and reveals lithologic and tectonic controls on the landscape. The major landforms, such as valleys and residual hills, developed in response to the uplift of the mountains and the deepening of the rivers since the beginning of the Cenozoic. The higher parts of the mountains were affected by glacial and periglacial erosion in the Late Pleistocene. Even the minor granite landforms, such as gnammas, appear to be older than the glaciation because they are only fully developed in non-glaciated areas.

Despite the need for more absolute dating of glacial sediments, there is no doubt that glacial dynamics affected 

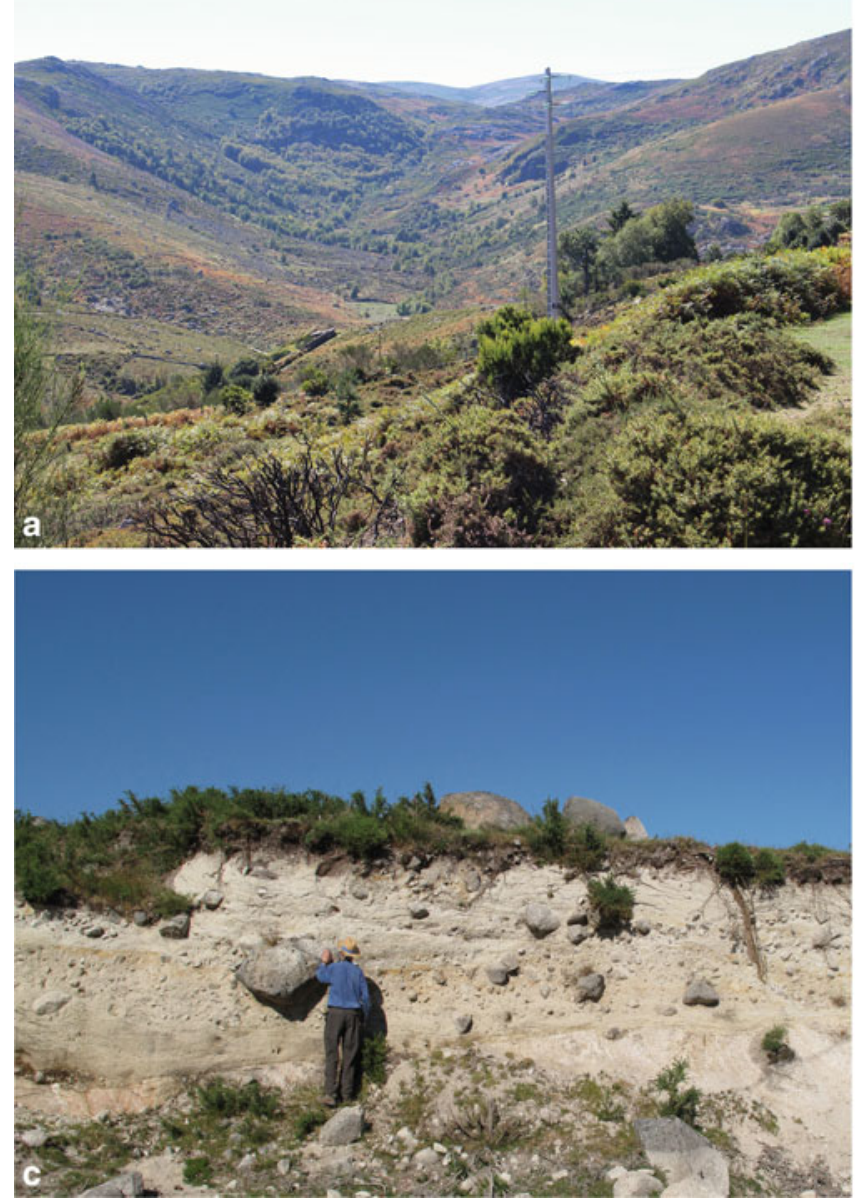

Fig. 10.9 Examples of glacial and periglacial landforms and deposits in the Peneda Mountain: a Vez river U-shaped valley, b Granite erratic boulders covering the schist slopes of Vez river valley close to Branda

the highest parts of the PGNP mountains. In addition to erosional landforms such as U-shaped valleys and glacial cirques, moraines and till deposits support the recognition of the extent and thickness of the glaciers at their maximum extent.

The aesthetic value of landforms of the PGNP has been recognised as one of the main reasons for the "wilderness" character that supported creation of this protected area back in the 1970s and is responsible for its growing attractiveness to tourists ever since. Moreover, the high scientific value of some of the granite and glacial landforms described here is the cause of their selection as geosites of national relevance and inclusion in the Portuguese inventory of geological heritage under the "Iberian Massif landscape and fluvial network" and "Vestiges of the Pleistocene glaciations" frameworks (Pereira and Pereira 2009; Pereira et al. 2015; Brilha and Pereira 2020).

Acknowledgements This work is co-funded by the European Union through the European Regional Development Fund, based on
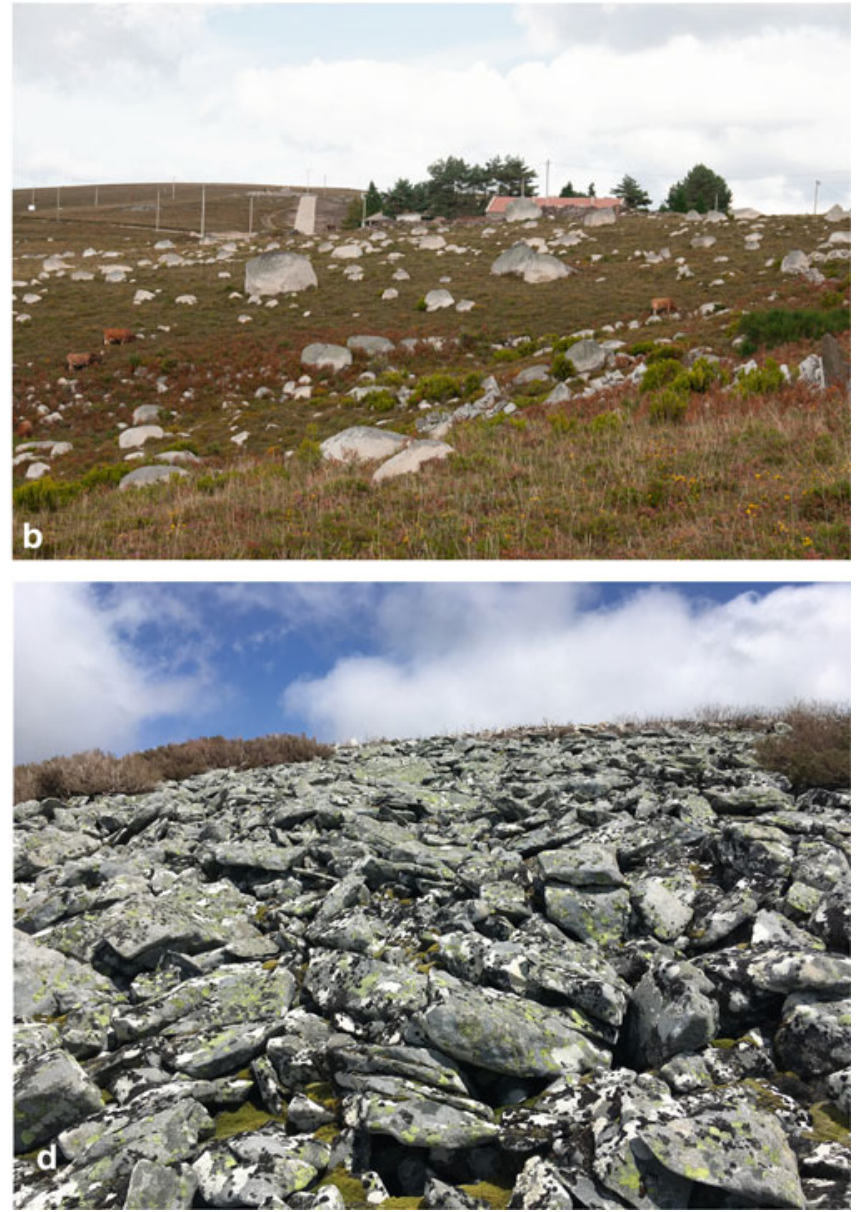

da Aveleira, c $3 \mathrm{~m}$ thick subglacial till outcropping near Branda da Junqueira, d Frost-shattered, angular granite slabs covering the highest slopes of the Pedrada summit

COMPETE 2020 (Programa Operacional da Competitividade e Internacionalização), project ICT (UID/GEO/04683/2013) with reference POCI-01-0145- FEDER-007690 and Portuguese national funds provided by Fundação para a Ciência e Tecnologia.

\section{References}

Brilha J, Dias G, Mendes A, Henriques R, Azevedo L, Pereira R (1999) The geological heritage of the Peneda-Gerês National Park (NW Portugal) and its electronic divulgation. In: Vallejo M, Gallego E (eds) Barantino D. Towards the balanced management and conservation of the geological heritage in the new millenium, Sociedad Geológica de España, pp 315-318

Brilha J, Pereira P (2020) Geoconservation in Portugal with emphasis on the geomorphological heritage. In: Vieira G, Zêzere JL and Mora C (eds) Landforms and landscapes of Portugal, world geomorphological landscapes series. Springer

Cabral J (2012) Neotectonics of mainland Portugal: state of the art and future perspectives. J Iberian Geol 38(1):71-84

Cloetingh S, Burov E, Beekman F, Andeweg B, Andriessen PAM, García-Castellanos D, De Vicente G, Vegas R (2002) Lithospheric folding in Iberia. Tectonics 21(5):1041-1067 
Cunha PP, Pimentel NL, Pereira DI (2000) Assinatura tectono-sedimentar do auge da compressão bética em Portugal, A descontinuidade Valesiano terminal-Turoliano. Ciências da Terra 14:61-72

Coudé-Gaussen G (1978) Confirmation de l'existence d'une glaciation würmienne dans les montagnes du NW du Portugal. Comptes Rendues sommaires de la Societé Geologique de France 1:34-37

Coudé-Gaussen G (1979) Les Serras da Peneda et do Gerês (Minho-Portugal): Formes et formations d'origine froide en milieu granitique. Thèse 3eme Cycle, Paris, $607 \mathrm{p}$

Coudé-Gaussen G (1981) Les Serra da Peneda et do Gerês. Étude géomorphologique. Memórias do Centro de Estudos Geográficos, 5, Lisboa, $254 \mathrm{p}$

Coudé A, Coudé-Gaussen G, Daveau S (1983) Nouvelles observations sur la glaciation dês montagnes du Nord-Ouest du Portugal. Cuadernos do Laboratório Xeolóxico de Laxe 5:381-393

Daveau S (1977) Um exemplo de aplicação da teledetecção à investigação geográfica. A glaciação quaternária das montanhas do Noroeste de Portugal. Finisterra 12:156-159

Daveau S, Coelho C, Costa VG, Carvalho L (1977) Répartition et rhytme des précipitations au Portugal, Memórias do Centro de Estudos Geográficos, 3, Lisboa, 192 p

Dias G, Leterrier J, Mendes A, Simões P, Bertrand J (1998) U-Pb zircon and monazite geochronology of post-collisional Hercynian granitoids from the Central Iberian Zone (Northern Portugal). Lithos 45:349-369

Fernández Mosquera D, Marti K, Vidal Romaní JR, Weigel D (2000) Late Pleistocene deglaciation chronology in the NW of the Iberian Peninsula using cosmic-ray produced ${ }_{21} \mathrm{Ne}$ in quartz. Nucl Instrum Methods Phys Res B 172:832-837

Ferreira AB, Vidal Romaní JR, Vilaplana JM, Rodrígues ML, Zézere JL, Monge C (1992) Formas e depósitos glaciários e periglaciários da Serra do Gerês-Xurés (Portugal; Galicia). Levantamento cartográfico. Cuadernos do Laboratorio Xeolóxico de Laxe 17:121-135

Ferreira AB, Vidal Romaní JR, Zézere JL., Rodrígues ML (1999) A Glaciação Plistocénica da Serra do Gerês. Vestígios geomorfológicos e sedimentológicos, Relatório 37, Centro de Estudos Geográficos, Lisboa, $150 \mathrm{p}$

Girão AA (1958) Glaciação quaternária na Serra do Jures. Boletim do Centro de Estudos Geográficos 11:13-22

Hughes P, Woodward J, Gibbard P (2006) Quaternary glacial history of the Mediterranean mountains. Prog Phys Geogr 30:334-364

Martínez de Pisón E, Arenillas M (1979) Algunos problemas de morfología glaciar en la España atlántica. Acta Geologica Hispanica 14:445-450

Martínez de Pisón E, Arenillas M (1984) Nuevos problemas de morfología glaciar en la España atlántica. Estudios Geograficos 175:159-174

Mendes A, Dias G (2004) Mantle-like Sr-Nd isotope composition of Fe-K subalkaline granites: the Peneda-Gerês Variscan massif (NW Iberian Peninsula). Terra Nova 16:109-115

Migon P (2006) Granite landscapes of the world. Oxford University Press, Oxford

Moreira A, Ribeiro ML (1991) Notícia explicativa da Carta Geológica do Parque Nacional da Peneda-Gerês à escala 1/50 000. Serviços Geológicos de Portugal e Serviço Nacional de Parques, Reservas e Conservação da Natureza

Oliva M, Palacios D, Fernández-Fernández JM, Rodríguez-Rodríguez L, García-Ruiz JM, Andrés N, Carrasco RM, Pedraza J, Pérez-Alberti A, Valcárcel M, Hughes P (2019) Late quaternary glacial phases in the Iberian Peninsula. Earth Sci Rev 192:564-600

Pereira DI, Pereira P, Santos L, Silva J (2014) Unidades geomorfológicas de Portugal Continental. Revista Brasileira de Geomorfologia $15: 567-583$
Pereira DI, Pereira P, Brilha J, Cunha PP (2015) The Iberian massif landscape and fluvial network in Portugal: a geoheritage inventory based on the scientific value. Proc Geol Assoc 126:252-265

Pereira P, Pereira DI (2009) Geomorfologia glaciária e periglaciária em Portugal. Contributo para a inventariação do património geológico português. Publicações da Associação Portuguesa de Geomorfólogos 6:279-284

Pereira P, Pereira DI, Casinhas P (2009) Novos dados sobre a glaciação no sector Gorbelas-Junqueira (Serra da Peneda). Publicações da Associação Portuguesa de Geomorfólogos 6:101-106

Pinto B, Partidário M (2012) The history of the establishment and management philosophies of the Portuguese protected areas: combining written records and oral history. Environ Manage 49:788-801

Rodríguez-Rodríguez L, Jiménez-Sánchez M, Domínguez-Cuesta MJ, Rinterknecht V, Pallàs R, Bourlès D, Valero-Garcés BL (2014) A multiple dating-method approach applied to the Sanabria Lake moraine complex (NW Iberian Peninsula, SW Europe). Quat Sci Rev 83:1-10

Santos J, Santos-González J, Redondo-Vega JM (2015) Glacial till-fabric analysis and origin of late quaternary moraines in the Serra da Peneda Mountains, NW Portugal. Phys Geogr 36:1-18

Santos J, Santos-González J, Redondo-Vega JM, Irwin JR (2017) Glacial deposits in the Serra do Gerês Mountains (NW Iberian Peninsula): till macrofabric analysis. Phys Geogr 38:263-285

Schmidt-Thomé P (1973) Neue niedrig gelegene zeugen einer wurmeis-zetlichen vergletscherung im nordteil der Iberischen halbinsel. Eizeitalter Und Gegenwart 24:384-389

Schmidt-Thomé P (1978) Nuevos testigos de una glaciación wurmiense extensa y de altura muy baja en el Noroeste de la Península Ibérica (Orense, España y Minho/Trás-os-Montes, Portugal. Cuadernos Sem Est Cerámicos de Sargadelos 37:221-243

Teixeira C, Cardoso JL (1979) A não confirmação de fenómenos glaciários nas montanhas do Norte de Portugal (Peneda-Gerês). Bol Soc Geol Portugal 21:163-184

Trigo R, DaCâmara C (2000) Circulation weather types and their influence on the precipitation regime in Portugal. Int $\mathrm{J}$ Climatol 20:1559-1581

Twidale CR (1982) Granite landforms. Elsevier, Amsterdam

Twidale CR, Vidal Romaní JR (2005) Landforms and geology of granite terrains. Balkema, Amsterdam

Vidal Romani JR, Ferreira AB, Zézere JL, Rodrigues ML, Monge C (1990a) Evolución Cuaternaria del relieve granitico en la Serra de Gerês-Xures (Minho-Portugal, Ourense-Galicia). Cuaternario y Geomorfología 4:3-12

Vidal Romani JR, Vilaplana J, Ferreira AB, Zézere JL, Rodrigues ML, Monge C (1990b) Los tills de la Serra de Gerês-Xurés y la glaciación pleistocena (Minho, Portugal-Ourense, Galicia). Cuaternario y Geomorfología 4:13-25

Vidal Romani JR, Vaqueiro M, Sanjurjo J (2014) Granite Landforms in Galicia. In: Gutiérrez F, Gutiérrez M (eds) Landscapes and landforms of Spain, world geomorphological landscapes series. Springer, Berlin, pp 63-69

Vidal Romaní JR, Fernández-Mosquera D, Marti K (2015) The glaciation of Serra de Queixa-Invernadoiro and Serra do Gerês-Xurés, NW Iberia. A critical review and a cosmogenic nuclide (10Be and $21 \mathrm{Ne}$ ) chronology. Cadernos Lab Xeolóxico de Laxe 38:25-44

Vieira G (1998) Periglacial research in the Serra da Estrela: an overview. In: Vieira G (ed) Glacial and periglacial geomorphology of the Serra da Estrela. Guidebook for the field-trip of the IGU Commission on Climate Change and Periglacial Environments. CEG and Department of Geography, Lisbon, pp 49-65, 26-28 Aug 1998 